\title{
ISLAMITIESE WETENSKAPSBEOEFENING?*
}

Die gyselaardrama in Iran het die bestaan van die Islam weer pertinent onder die aandag van die wèreld gebring. Sedert hierdie gebeurtenis aan die einde van 1979 het dit ook algaande duidelik geblyk dat die Islam 'n godsdiens is waarmee rekening gehou behoort te word. Dit het verreikende politieke, maatskaplike en selfs militêre en internasionale implikasies. Hier is 'n geestelike mag aan die werk wat potensieel die moontlikheid besit om die wêreld in 'n derde wêreldoorlog te dompel. Op alle fronte blyk verder ook 'n sterk herlewing van die Islam sodat dit duidelik begin word dat dit ' $n$ mag is waarmee terdeè rekening gehou behoort te word.

Ook op die front van die wetenskapsbeoefening geld hierdie laasgenoemde stelling. In die toonaangewende tydskrif Nature van 22 November 1979 verskyn 'n artikel waarin berig word dat ondersoek in agt sleutelstate van die Moslemwêreld Iran, Turkye, Siriě, Saudi Arabiě, Egipte, Pakistan, Maleisië en Tunisië 'n toenemende belangstelling in die hele konsep van Islamitiese wetenskap aan die lig gebring het - 'n sosiaal-betrokke wetenskap wat ontwikkel moet word binne die raamwerk van die filosofie van die Islam.

Die Moslemwêreld is besig om deur 'n diepgaande proses van selfondersoek en vernuwing te gaan. Van hierdie proses maak die hele herwaardering van die wetenskap en by name ' $n$ wetenskap in harmonie met die waardes van die Islamkultuur en -samelewing ' $n$ integrale deel uit.

Afgesien hiervan het die herlewing van die Islam ook'n belangrike bydrae gelewer tot die ontwikkeling van die wetenskap en wel omdat die Koran op nie minder as 750 plekke (amper cen agtste van die inhoud van die Koran) die gelowige Moslem aanmoedig tot die studie van die natuur, besinning en die gebruik van die rede en die inskakeling van die wetenskapsbedryf in die gemeenskapslewe.

In die geskiedenis van die Islam beklee die wetenskap 'n sentrale posisie. Die wetenskap het dan ook 'n kragtige effek gehad op die ontwikkeling van die Moslem-beskawing. Dit word dan ook al hoe meer besef dat die wetenskap in die toekoms 'n baie sterk rol gaan speel in die ontwikkeling van 'n Moslembeskawing. Twe belangrike faktore het tot die ontwaking van hierdie besef en die herlewing van die idee van Islamitiese wetenskap aanleiding gegee:

Die eerste faktor was die publikasie van die boek van Seyyed Hossein Nasr, Science and civilizarion in Islam (Harvard university Press, 1968). Hierdie werk was 'n eerlike poging om Islamitiese wetenskap te ondersoek binne die konteks van die beskawing van Islam. Sy tweede werk Islamic Science (Festival Trust, London, 1976) het die saak van Islamitiese wetenskapsbeoefening na 'n meer populère vlak geneem en het heelwat opspraak op kampusse van Islamitiese universiteite veroorsaak. Die tweede belangrike faktor wat tot die herlewing van die Islam en die idee van Islamitiese wetenskapsbeoefening bygedra het, was die Islamitiese 
Solidariteitskonferensie oor Wetenskap en Tegnologie wat deur die universiteit van Riyadh in Maart 1.976 gorganiseer is. Hierdie konferensie het heelwat tyd bestee aan die vraag hoe Islamitiese wetenskap beoefen moet word en hoe dit daar uitsien. Wat hier vir die Moslemwêreld wel duidelik geword het, was die feit dat die voortbestaan van die Moslemgeloof tot 'n hoë mate saamhang met die herlewing van wetenskap "in die lig van" die Islam.

Sedert 1976 was daar dwarsoor die Moslemwéreld 'n groot verskeidenheid poginge om die gees van die Islam in die natuurwetenskappe te blaas, om die onderrig van wetenskap te Islamitiseer.

\section{VERSKILLENDE STANDPUNTE}

Die gesprekke oor Islamitiese wetenskapsbeofening sentreer rondom twee grondvrae:

- Wat is Islamitiese wetenskap?

- Hoe verskil dit van die konvensionele praktyk van wetenskapsbeoefening?

Sommige Islamwetenskaplikes vra egter nog veel meer fundamentele vrae, naamlik of daar so iets soos Islamitiese wetenskap is. Vier standpunte kan met betrekking tot hierdie sake onderskei word. Die eerste is die tradisionele Westerse wetenskaplike etos. Die tweede standpunt en die derde standpunt hou beide vol dat die Islam veel te sê het oor die wetenskap, maar verskil oor die vraag waar die Islam presies binne die prentjie kom. Die vierde standpunt argumenteer dat Islamitiese wetenskap iets radikaal anders is as wetenskap soos dit vandag gangbaar beoefen word.

Die eerste standpunt stel onomwonde dat daar slegs een tipe van wetenskap is: Universeel, neutraal en waardevry. Die studie van die natuur is onpersoonlik en vry van menslike waardes. Hierdie grondliggende rasionaliteit van die objektiewe wetenskap kan nie gekompromiteer word met die religieuse belange van die Islam nie - so word geredeneer. Vir vele wat hierdie standpunt toegedaan is, beteken die Islamitisering van die wetenskap eintlik meer die uiteindelike beoefening van die wetenskap via die Arabiese taal. Daar is egter 'n groot aantal wetenskaplikes wat redeneer dat die hele vraagstuk van Islamitiese wetenskapsbeoefening dieper gaan as bloot net die beoefening van die wetenskap in die Arabiese taal.

In die tweede posisie word daar uitgegaan van die gedagte dat wetenskap neutraal is, maar dat die houding waarmee die wetenskap benader word sekulêr of Islamities kan wees. Waarin bestaan nou die tipes Islamitiese benadering tot die wetenskap? Die erkenning dat die menslike rede en gees begrensd is en die erkenning dat alle kennis die besit van God is. Hierdie kennis word aan die mens in bruikleen toevertrou en dit kan deur die mens op 'n konstruktiewe of 'n destruktiewe wyse aangewend word. Hier gaan dit dus om die gebruik of misbruik en die toepassing van die andersins waardevrye en objektiewe kennis. Die besef dat hierdie kennis 'n effek het op die samelewing moet daartoe aanleiding gee dat diskresie uitgeoefen 
word in die tipe projekte wat onderneem word en die wyse waarop wetenskap beoefen word. Vir Zafar L. Sawafm, direkteur van die Sentrum vir Industriële Navorsing en Ontwikkeling in Sirië, geld die eis dat die gebruik van die wetenskap in die samelewing deur die Islam bepaal moet word. 'n Islamitiese benadering tot die gebruik van die wetenskap sal Sirië daarvan weerhou om dieselfde weg van materialisme en die oordadige verbruikersroes op te gaan wat so kenmerkend is van die effek van die Westerse wetenskap op die Westerse samelewing.

Die derde groep plaas ook 'n sterk aksent op die behoud van Islamitiese waardes. Hierdie groep stel egter voor dat Islamitiese wetenskap veel meer te make het met 'n filosofiese instelling as met die wetenskap as sodanig. Wetenskap is van nature tipies Westers - so word daar geredeneer. Omdat Mulsmim-wetenskap konstant die lakei is van die Westerse wetenskap, tegnologie en waardes, is dit in 'n stryd gewikkel.

Ali Kattanie, professor van Elektriese Ingenieurswese aan die Universiteit van Petroleum en Minerale te Baharan in Saudi Arabië, beweer dat Islamitiese wetenskap die behoeftes en die aspirasies van die Muslimbevolking reflekteer. Hy sê: "Western science places man at its centre, in the position of a demi-god. Islamic science emphasises the position of man in the universe: he can rise to the level of angels or sink to unimaginable depths, but he is responsible for all his actions, and the after-effects of his action, to a Supreme Authority. Seientific activity carried out under such a realisation is an intirey different proposition. The actual content of such a science may uot be radically different. But the priorities and emphasis will certainly be different. And so will the quality and the quantity of the content of this science. And finally, the use to which this science will be put will also be different". (Naturt, vol. 282, 22 Nov. 1979, p. 357). Ander woordvoerders van hierdie standpunt beklemtoon voorts die feit dat wetenskap, wysheid en waardes integraal verbonde is en dat eersgenoemde twee faktore rigting gee aan die denke van die mens.

Die vierde standpunt met betrekking tot Moslemwetenskap beklemtoon ook die sosiale funksie van die wetenskap, maar redeneer dat Islamitiese wetenskap 'n unieke en eiesoortige entiteit is wat drasties verskil van die tipe van wetenskap wat vandag gangbaar beoefen word. Die voorstanders van hierdie standpunt argumenteer dat die wetenskap soos ons dit vandag ken sy inspirasie trek van die Verligting en sy vooronderstellings is dié van die Philosophes en die rasionalistiese wêreldbeskouing. Sommige van die onderliggende vooronderstellings van die wetenskap is die van die Middeleeuse Christendom, is 'n produk van die Westerse kultuur en 'n vergestalting van die Westerse kultuur, etos en waardes.

Die voorstander van Islamitiese wetenskapsbeoefening redeneer dat hierdie tipe wetenskap gebaseer is op totaal-verskillende veronderstellinge oor die verhouding tussen mens en medemens, die mens en die natuur, die kosmos, tyd en ruimte. Omdat die aksiomas van die lslamitiese wetenskapsbeoefening verskillend is van dié van die Westerse wetenskap en die wyse waarop dit tot kennis kom ook van die van die Weste verskil, is dit ' $n$ wetenskap met sy eie identiteit en karakter. 
Wetenskap word deur voorstanders van hierdie standpunt gesien as ondergeskik aan die doelwitte van die samelewing. Die doelwitte van die Islamitiese samelewing is die vermeerdering van broederskap, die vermindering van verbruik en die verhoging van geestelike bewuswording. 'n Wetenskap met hierdie doeleindes sal radikaal verskil van 'n wetenskap beoefen met die oog op ander doeleindes. Voorts kan hierdie doeleindes nie deur enige denkbare middel bereik word nie, maar slegs deur daardie middele wat deur die Islam toegelaat word.

Dit is interessant dat hierdie vierde radikale standpunt, veral in die postrewolusionêre Iran gehuldig word. Moslem-wetenskaplikes beweer dat hulle nie korttermynoplossings vir die probleme van die samelewing soek nie. Die aksiomas van die Islamitiese wetenskap, sy mensbeskouing, opvatting van die natuur en die omgewing en die kosmos - "... do not permit Islamic science to become a part of a system of violence - and violence is defined here in very broad terms - or of a system of power and control" beweer Mahdi Mumkuns, Adjunkminister van die nuutgestigte Ministerie van Nasionale Voorligting in Iran (Nature, vol. 282, 22 Nov. 1979 , p. 357).

'n Ander woordvoerder van hierdie vierde standpunt artikuleer die posisie nog duideliker: Islamitiese wetenskap, sê hy, is epistemologies en ontologies onlosmaaklik verbonde aan die Islamitiese konsep van God. Wanneer hy die inhoud van hierdie wetenskap moet weergee, dan sê hy dat Islamitiese wetenskap "public interest science" is, beoefen binne die parameters van die Islamitiese opvatting van die "algemene belang" wat uiteenval in vyf prinsipes, naamlik die Islamitiese lewenswyse, die lewe self, rede, die behoud van 'n nageslag en eiendom.

Die kort weergawe en oorsig van standpunt in die Moslemwêreld laat al gou sien dat die Moslemwetenskaplike voor dieselfde grondliggende vraagstukke te staan kom as die voorstander van die idee van Christelike wetenskap. Die posisie wat hier ter sprake kom, sou goedskiks net so ook op die verskeidenheid van benaderinge van die idee van Christelike wetenskap oorgedra kon word.

Tog plaas hierdie artikel die Christelike wetenskaplike ook voor belangrike vrae. Die gebeure in Iran en die houding teenoor die tipe kultuur en beskawing wat deur die Shah van Iran uit die wetenskaplike- en kutuurskat van die Weste ingevoer is, spreek onomwonde van die onbewuste, dog duidelik ideologiese geladenheid van die Westerse wetenskap. Die Westerse wetenskap en tegnologie het tot 'n hoë mate die draer geword van die materialistiese konsumpsie-etos van die Weste met sy onversteurbare geloof in die mag van die rede, wetenskap en die tegnologie. Die voorstanders van die Islamitiese wetenskap laat duidelik sien dat 'n ontideologisering van hierdie inherente ideologiese geladenheid van die wetenskap noodsaaklik is. Miskien is die kardinale punt hier die feit dat enige religie wat 'n transendente godheid erken noodwendig kritiek moet uitoefen op die grondliggende ideale ten grondslag aan die moderne wetenskap en tegnologie: die ideale van mag, beheersing en tegniese kontrole deur die rede van die mens. 
Andersyds laat hierdie standpunt ook duidelik sien dat wetenskap 'n bedryf is wat deel uitmaak van 'n groter kultuur-en waardesisteem en as sodanig nooit volledig waardevry, objektief en neutraal kan wees nic.

Miskien is die belangrikste element van al die bogenoemde standpunte die ontmaskering van die idee dat die Westerse wetenskap so waardevry en neutraal is as wat dit so graag wil voorgee om te wees, terwyl die grenslose uitbreidingsdrang van die Islam Christenwetenskaplikes weer tot stilstand en besinning behoort te roep.

- Hierdie is 'n weergawe, in hooftrekke, van 'n artikel deur Zia Sardar (A revival for Islam: a boost for science?) wat in die tydskrif Nature, bd. 282 van 22 November 1980 verskyn het en wat goedgunstiglik onder die aandag van die redaksie gebring is deur dr Louw Alberts. 